\title{
BOBOS E PALHAÇOS: A ESTÉTICA DA SO(M)BRA
}

\author{
Aldo Antônio Tavares do Nascimento ${ }^{1}$ \\ Faculdade de São Bento do Rio de Janeiro (FSBRJ)
}

\section{RESUMO:}

Este artigo se propõe a refletir sobre um leque de conceitos inerentes à alegria por meio de figuras que encarnam a estética da sobra, neste caso, o bobo e o palhaço. Dos gregos até o final do século 19, a filosofia permaneceu a pensar o que é sério. Em 1677, com a publicação de Ética, Baruch Spinoza pensou os afetos, um deles, a alegria, ainda que a tenha pensado com a retidão de um geômetra. A escrita spinoziana é o sério que pensa a alegria. Somente na segunda metade do século 19, Friedrich Nietzsche alegra a escrita filosófica. Em um mundo onde crianças cada vez mais ignoram o sentido do bobo e do palhaço para a vida, refletir sobre a alegria neste artigo é tentar devolver a essa palavra sua profunda originalidade, sentido ausente em dias hodiernos.

PALAVRAS-CHAVES: Criança; Brincar; Práxis; Poíesis; Capitalismo.

\section{FOOL AND CLOWNS: THE SHADOW OF AESTHETICS}

\begin{abstract}
:
This article intends to reflect on a range of concepts about joy through figures that embody the aesthetics of plenty, in this case, the fool and the clown. From the Greeks to the late 19th century, the philosophy remained thinking what should be considered serious. In 1677, with the publication of "Ethics", Spinoza thought about the affections, one of them, the joy, even though he had done it with the righteousness of a geometer. The Spinozian writing is the joy wondered by the seriously. Only in the second half of the 19th century, Friedrich Nietzsche rejoices philosophical writing. In a world where children increasingly ignore the sense of fool and clown for life, think of the joy on this article is to try to return to that word in its deep originality, absent sense nowadays.
\end{abstract}

KEYWORDS: Child; Mock up; Praxis; Poíesis; Capitalism.

\footnotetext{
${ }^{1}$ Professor de Filosofia da Faculdade de São Bento do Rio de Janeiro (FSBRJ), Rio de Janeiro - Brasil. E-mail: lingua.portuguesa@uol.com.br
} 


\section{E no princípio era o verbo... alegrar}

Defendem alguns que o aluno de Tales de Mileto, Anaximandro de Mileto (nascido talvez em 611 a.C, século VII), porque cunhou o termo arché para designar o primum, tenha sido o primeiro filósofo do Ocidente, enquanto Heráclito de Éfeso (por volta dos anos 544 a.C - 474 a.C, século V) cunharia a palavra filosofia, cuja etimologia é ser "amiga do saber"; saber que pergunta o que é. Em grego, "perguntar" é eroto; e "pergunta", erotima. O sentido profundo da palavra "pergunta", acolhido pelo significante grego erotima, morreu no exato momento em que se transliterou esse significante para o latim vulgar como praecunto e para o latim clássico como percontāre. Com efeito, se em latim "pergunta" implica "o todo inteiro", em grego o sentido da palavra "pergunta" (erotima) acessa a ideia mítica do deus Eros e, assim sendo, habita, na própria palavra erotima, a ação de cortejar ou de enamorar o que é, visto que, por ser impulso que nos aproxima em direção ao que é, "perguntar" em grego nos movimenta ao encontro do íntimo. Se a filosofia, ao ver, pergunta, é porque o que é visto atrai; mas o atrair, sabemos, que namora o que é, já mora na pergunta. Uma vez atraída, a fillosofia, que vê, pergunta, sabendo que perguntar já é atração.

Mas por que pergunta o que é e não o que está? Em latim, sedēre (estar sentado) diferencia-se de siděre (sentar-se), mas ambos usavam o particípio sessum, gerando as bases sid-, sed- e ses.s-, que em português torna-se $s(e)$-. Essas morfologias se encontram em "sedentário, assentam, sede, sé, senta"; quem se senta à frente da reunião é "presidente"; povos "sedentários" passam a "residir". Como observamos, os exemplos relacionam-se à constância do ser, e não à transitoriedade do estar. Quando a filosofia pergunta o que é, pergunta porque só pode ver o que ée, só pode ver o que não é transitório, o que não é inconstante - a amiga do saber não pode ver o que não é.

Mas qual o sentido de ver? Para o grego antigo, ver e saber iguala-se, talvez por o motivo de "sabor" e de "saber" ter a mesma origem etimológica, havendo, por conseguinte, "sabor" na ação de ver. Toda experiência dos sentidos limita. No caso da ação de ver, emoldura-se o campo de visão ou o próprio campo de visão é a moldura. Ver, portanto, é isto: ao enquadrar, a experiência corta e pergunta o que é. Por causa do corte, cada ser é; por causa do talho, o ser não é com o todo restante, não é com os outros seres.

Uma vez cortado para só então perguntar o que é, sabendo que só é cortado por ser repouso, não transitório, a amiga do saber agora pode pensar o que perguntou após ver. Antes, no entanto, aproximemos o que o senso comum mantém distante: "pensar" e "pesar" ou "penso" e "peso" se avizinha na etimologia, tanto que pensar é pesar a palavra sobre a linha do papel. Quando muito bem pensada, a palavra é peso e, de tão pesada, não se move mais na superfície da linha; imóvel por causa de seu peso, a palavra 
altera a linha contínua da superficialidade, causando no fio desnível. O movimento do peso agora é vertical, ou seja, o movimento do peso desviase da superfície; separa-se da superficialidade da linha em direção ao fundo, isto é, à medida que o peso aprofunda, o movimento do pensar fundamenta. A isso, relacionemos mais uma palavra capital: quando a filosofia viu e perguntou o que é, havia já, na natureza de ver e da dúvida, ela: palavra que também, em latim, pesa - serium.

Entretanto, conforme o mito do período arcaico, os sete deuses que governam o mundo não surgiram da substância, do peso ou do que é sério. Lê-se no papiro anônimo e alquímico de Leyde, século III, que a origem dos deuses é por causa de um Deus que, sete vezes, riu. Então, antes de o primeiro filósofo sério surgir na Grécia Antiga, Deus, o Único, já havia gargalhado. Será que cômico e cósmico possuem a mesma origem etimológica?

\section{Seria leve se não fosse sério}

Em grego, há dois tipos de riso: o "simples" é gelân; e katagelân, o "riso agressivo". Simples ou agressivo, o riso é movimento contra a separação das partes em direção à integridade, ao inteiro, ao completo, ao que não falta. Para Heráclito de Éfeso, se os deuses gargalham, é porque simboliza a alegria inteligente diante da união da Discórdia (Ares) e do Amor (Afrodite), anulando partes isoladas, o que resulta em harmonia. $\mathrm{O}$ riso é esse movimento direcionado a duas partes que se integram, elas: a Discórdia e o Amor. "Era legítimo que os deuses rissem diante desse espetáculo e se regozijam juntos, pois, uma vez que eles parassem de divergir e de se destruir, suas benfeitorias particulares produziram a paz e a concórdia" (MINOIS apud HERÁCLITO, p. 50).

Embora sejam "riso simples" (gelân) e "riso grosseiro" (katagêlan), há nesses dois termos a partícula ge. Em Teogonia, a origem dos deuses, Hesíodo registra Gaia, e a tradução em latim é Geia (ge-o), Terra. Então, do grego $\gamma \tilde{\eta}$ (som guê), o latim aproximou para ge. Sócrates em Crátilo, de Platão, afirma que o significado da terra ( $g e$ ) se tornará mais evidente se recorrermos à forma gaia, pois terra quer dizer precisamente "mãe" (gennêteira), ou seja, aquela que gera. Há em ge, por conseguinte, o sentido duplo em harmonia: movimento-origem, gênese-movimento, geração-gênero ou força produtora-nascimento.

Assim como Geia, aquele que ri também se dilata; fica cheio dentro de si, pois, sendo movimento no interior de si mesmo, o riso, ao movimentar, gera em nós o excesso de pneûma, quer dizer, "sopro, ar" ou vida, não havendo outra finalidade desse excesso senão "estar fora" ou "existir". Se rir é estar animado, o riso é anima - o que vem de dentro em direção ao que está fora ou o que vem do não ser ao ser. 
Geógrafo e viajante grego, Pausânias (115 d.C - 180 d.C) conta que havia um estranho riso em Lebadeu, na gruta profunda e escura de Trofônio, onde o iniciado devia simular a morte. Levado pelos sacerdotes, ele era entregue a seus amigos, e sua ressurreição era manifestada pelo riso:

\begin{abstract}
Aquele que retornava depois de ter consultado Trofônio era logo cercado pelos sacerdotes, que o faziam sentar-se sobre o que chamavam de Trono da Memória. Quando estava sentado, eles lhe pediam para contar o que vira e aprendera. Recolhidas essas informações, os sacerdotes as repassavam a seus próximos. Estes o levantavam e o levavam para o quarto, onde ele encontraria, doravante, Boa Sorte e Bom Gênio. Ele era ainda acometido pelo medo, não sabia quem era, não reconhecia os familiares. Um pouco mais tarde, contudo, recobrava toda a consciência e recuperava a faculdade de rir. (Ibid, 2003, p. 25).
\end{abstract}

Esse exemplo ilustra que o riso associa-se à morte, ao não ser. O iniciado entra na escuridão para sair dela com os segredos que serão contados somente aos sacerdotes, com a condição depois de o visitante esquecer o que viu no mundo sobrenatural; mundo que, velado aos homens comuns, não é. Entendamos como não ser o que, por simular a morte para penetrar no mundo divino, significa sombra, do latim vulgar sulumbra (de sub illa ümbră), que, por ser sombra, in-verte a imagem do modelo. A sombra é o verso. Mais: como ūmbră também significa em grego "porta" ou "passagem" para um grau mais interior, o iniciado vai à gruta profunda e escura de Trofônio porque, quando estiver atravessando o limiar, a soleira da porta, ele sabe que, uma vez realizada a passagem, ficará ocultado não pelo Caos ou pelo Érebo mas pela deusa Nix (noite). Segundo os gregos, o morto nesse ritual transformava-se em ídolo (eídōlon), em imagem - melhor: em corpo insubstancial.

No mundo de Nix, não existe o filósofo ou o amigo do saber sério, que pensa a fim de se movimentar em direção à substância, porque, na escuridão, o filósofo sério não pode ver para perguntar o que é. Para saber o que é no mundo de Nix, ele perderá toda seriedade de pesar a palavra, pois, para saber o que é, a experiência da visão - que na escuridão é o mesmo que vagar - deve ceder a dois sentidos que Aristóteles hierarquizou como os últimos, quais sejam: o tato e o paladar. Todavia, na noite, o que existe é não só a constância do movimento ou a constância do inconstante, mas o perigo da sobra. Aqui, para saber o que é, a filosofia - que não vê, e não pergunta porque não vê - só pode tocar no transitório, que é não é.

Caso exista algum amigo do saber no mundo de Nix, ele se chama poeta; saber que não só se difere do saber epistêmico do filósofo sério como também se opõe a ele por ser o poeta, segundo Íon, concessão e possessão divinas, proporcionando abundantes formas e abundantes palavras, manifestadas em ditirambos, em encômios, em pantomimas. Nessa obra de 
Platão, o que é divino é, como o riso, farto, sobra. Por sua etimologia e por sua história, o riso habita o universo da escuridão, mesmo porque Momo, que tanto ri, é um dos filhos de Nix, e, por analogia, o Bobo também é.

Embora seja filha do Caos, Nix não é a escuridão cega, absoluta, visto ser mãe de Emera, divindade feminina que personifica a claridade, o dia. Embora tenha criado a sucessão do tempo e tê-lo dividido em horas, Nix, em si mesma, não é tão clara e tão distinta, não separando nela os elementos como Emera os separa. A ordem noturna ainda mistura, ainda confunde, assemelhando-se à ordem caótica, diferenciando-se, porém, à do Caos quanto, por exemplo, à divisão dos quatro horizontes - enquanto Nix posiciona-se a Oeste, Caos amalgama os pontos cardeais.

\section{Ruínas sob significantes \\ Bobo}

Abrir os dicionários grego-português-grego e latim-português-latim a fim de saber o significado da palavra e depois buscar o sentido dela na história da filosofia não deixa de comprometer o próprio entendimento da palavra. Sempre se perde algo. Em A Origem da Obra de Arte, Martin Heidegger (1889-1976) afirma que, por detrás da tradução, aparentemente literal e com isso preservadora, esconde-se muito mais um transpor da experiência grega para um outro modo de pensar. Quem pensa semelhante é o historiador Reinhart Koselleck (1923-2006) na palestra Uma História dos Conceitos: problemas teóricos e práticos, ao exemplificar com o conceito de Koinonia politike de Aristóteles, traduzido como republica ou também como societas civilis. Podemos afirmar com isso que, se o pensar brasileiro assume as palavras latinas depois de "o pensar romano ter assumido as palavras gregas, traduzidas sem a experienciação igualmente originária que corresponda ao que elas dizem, sem a experiencial palavra grega" (HEIDEGGER, 2010, p. 53), então, do grego ao português, muito se perdeu nessa travessia.

Personagem do romance 1984, de George Orwell (1903-1950), Syme, filólogo e lexicógrafo, possui a função social de publicar a $11^{\mathrm{a}}$ edição do Dicionário Novilíngua ${ }^{2}$ como definitiva, e será definitiva porque Syme está dando à língua sua forma tão final que a prole terá de aprender as palavras outra vez; elas estão sendo destruídas para essa edição às dezenas, às centenas, todos os dias, reduzindo a língua à expressão mais simples. Syme destrói palavras e, ao destruí-las, estreita-se, por causa da eliminação de substantivos, o pensamento.

\footnotetext{
${ }^{2} \mathrm{~A} 11^{\mathrm{a}}$ edição alude à $11^{\mathrm{a}}$ tese contra Feuerbach, onde não basta entender mas transformar, no caso, a mente da prole por meio das palavras. Membro do partido, Syme vive em Oceania, país totalitário em que o poder exerce sua função transformadora sob a aparência neutra do significante.
} 
A literatura do passado terá sido destruída, inteirinha. Chaucer, Shakespeare, Milton, Byron - só existirão em versões Novilíngua, não apenas transformados em algo diferente, como transformados em obras contraditórias do que eram (ORWELL, 1984, p. 53).

Entre tantas palavras destruídas ao longo dos séculos, bobo é uma dessas que perdeu sua força, sendo não só diferente como também palavra contraditória do que foi. Registrada pela primeira vez em 1597, bobo provavelmente do latim balbus - significa "aquele que pronuncia mal, gagueja", porque sabe que o espírito epistêmico ou lógico do filósofo sério "é erro ou pobreza, porquanto, ante o mistério do mundo, não sabemos senão balbuciar" (JOLIVET, 1960, p. 64). Depois de o riso perder sua função religiosa na Grécia antiga, o bobo torna-se somente "aquele que faz rir" ou gêlotopoios, palavra composta por ge - a mesma encontrada em gêlo (riso simples) e em katangêlo (riso agressivo) -, cujo sentido é "movimento, criar, nascer, origem, encher, atulhar, repleto, alegre".

Houve época em que o bobo sentava-se à esquerda do rei, ao lado de quem rege, de quem governa, organiza; o bobo sentava-se ao lado do centro, do eixo, da linha reta; sentava-se ao lado esquerdo do cardo. O bobo, portanto, imposturava no (seu) ponto cardeal, à esquerda do ponto fixo, isto é, ele transbordava o lugar a oeste do rei, onde fica o poente ou onde se declinam as metáforas do Sol. Após um dia de cansaço, dia de trabalho injusto a serviço de quem im-põe, o Sol se declina para que a noite acolha e cubra os corpos de descanso, de sono, de sonho, de fantasia, de sombra. Oeste significa noite.

Já sabemos que estar à esquerda é estar no poente, o que ainda não sabíamos é que esquerda vem do grego aristera, etimologicamente "excelente, ótimo", uma vez que aristera se prende ao superlativo aristos, "o melhor, o mais nobre, o exímio, o magnífico". Ora, se o bobo eleva-se à medida que o Sol se põe, ao cair da luz, justifica-se então o porquê de o bobo ser excelente, pois, à proporção que o dia se retira de cena, o que se encontrava retido em si mesmo por causa da luz, aos poucos, excede-se. Quando dizemos que ele é excelente, reconhecemos que não só se excedeu como se excedeu, no caso do bobo, com "graça". Por não estar à direita da ordem fixa do rei, o bobo é aquele que, não agindo por conveniência, não estando de acordo com a aparência do dia, senta-se à esquerda de quem governa para se exceder e, excedendo-se, ouve aqueles que se excederam à noite em suas fantasias, delírios oníricos em desacordo com a ordem do dia.

A palavra direita em latim é dextera ou dextra, podendo se aproximar de decet por etimologia popular, que significa "o que é conveniente". Dextra tem a mesma raiz em grego, deksiá, cuja ideia é "de bom augúrio, favorável". Enfim, se o bobo não se posiciona à direita, é porque não representa, por não se exceder, a segurança do Leste - do grego 
eós, "aurora, alvor do dia"; e do latim oriens, "o que nasce". Por isso, ele se encontra à esquerda, porque o bobo representa, ao se exceder, perigo que se manifesta por vir do Ocidente - do latim occidens e do grego disi, "onde morre o Sol".

Mas por que perigo? Sendo rebento de Nix que atravessou a fronteira entre a escuridão e a luz para se sentar à esquerda de quem im-põe, o bobo é o noturno que se fan-tasiou de bobo a fim de, ocultando-se, descobrir, à luz do dia, o que o Sol oculta. O bobo, sombra que impostura a fim de que a clarificada "verdade" das coisas diurnas, encobertas pela própria luz do dia, ponha-se do avesso.

Isso bastaria para o bobo ser perigo; isso, entretanto, não diz o que é, por ele mesmo, o sentido de perigo. Em grego, perigo é kindinos, derivado do verbo kino, "mover". Se tudo fosse imóvel, qual perigo nos ameaçaria? Se tudo fosse fixo, não haveria traço. Movimento é perigo. O segundo significado de perigo, este: risco. $\mathrm{O}$ movimento ou o perigo risca, quer dizer, o movimento delineia, divide, separa. Ora, quem não arrisca não demarca nenhuma linha, por isso permanece no mesmo e único lugar, o que não deixa de ser conveniente. Também quem não risca não tem como e nem o que escolher. No entanto, se o bobo atravessou o perímetro entre a noite e o dia para se sentar à esquerda do rei, ele, com sua plasticidade, riscou e se lançou, entre os mortais, à luz das horas - elã dos sentidos enquanto corpo oblíquo que expressa a força metafórica do noturno.

Ainda no grego, risco traz outro significado - e relacionado ao anterior -, que é o de plano, cuja origem relaciona-se a "plástico". O risco é extensão, por isso o terreno plano é terreno que se estende, superfície do traço que se alarga. E aqui o termo risco adquire outro significado, só que desta vez desorganiza o leitor menos atento, qual seja, risco é "erro, engano, ilusão". Em grego, plastos é "falso". Não querendo antecipar reflexões sobre o sentido de risco enquanto "erro, engano, ilusão, falso", sintetizemos neste parágrafo que o bobo é perigo porque seu movimento, um risco, é a experiência da plasticidade.

No parágrafo anterior, um termo não pode passar aos olhos sem reflexão: experiência (em grego, empeiria). Segundo Agamben, empeiria contém, de fato, a mesma raiz de praxis (ação, fazer), e praxis, por sua vez, vem de pira (eu atravesso), sendo etimologicamente conexa a pera (além), a poros (passagem, porta) e a peras (limite). Por causa dessa origem, experiência é "movimento para ir através de uma passagem que vai até o limite". Em Metafísica (Livro V, 1022 $2^{\mathrm{a}}$ ), de Aristóteles, o limite não é externo à ação, porém na própria ação. O limite é na ação; na ação, o limite. A praxis, que é ação, que é fazer, é limite na ação mesma. No Livro I, 981 ${ }^{\text {a }}$, esse fim na ação tem natureza particular, quer dizer, não é universal. No limite da praxis, "os trabalhadores manuais agem, mas sem saber o que fazem, (...), os trabalhadores manuais agem por hábito" (ARISTÓTELES, pág. 5, 2013). Ora, se os trabalhadores manuais ignoram o que fazem, é 
porque, sendo a praxis ação de natureza particular, esse trabalho, na própria ação, não se articula para além de seu limite, mesmo porque a praxis não se vê em um todo universal e muito menos em um todo articulado. A natureza particular da experiência ou da praxis é, portanto, parte isolada. O bobo, que nem trabalhador é, não pertence à natureza do particular, não age por hábito. Sua experiência plástica é tékhne, arte; e, ao ser arte, seu conhecimento relaciona-se às ciências poiéticas. Nesse sentido, o bobo é perigoso, plasticidade poética que se arrisca a ultrapassar o perímetro que separa Nix da filha Emera.

Por causa desse perigo, em 389 d. C, Teodósio e Velentiano II eliminam as festas do calendário. Em 395, Arcadius proíbe no feriado nos dias de festas pagãs. Em 425, Teodósio e Velentiano II proscrevem divertimentos, comédia e circo no domingo e nos dias de festas religiosas. $\mathrm{O}$ Concílio de Cartago, em 398, excomunga aqueles que deixam a igreja para ir a espetáculos em dias de festa. O Concílio de Tours, em 567, condena as torpezas pagãs que acompanham as festas de fim de ano, que substituíram as saturnais e passaram a ser chamadas de festas dos loucos; o de Toledo, em 633, reitera a condenação. Tantos interditos só denunciam o quanto perigoso foi nesses anos o excesso político de gêlotopoios, não conseguindo a Igreja, mesmo com tais proibições, subtrair a festa do bobo. Isso, porém, não indica que o riso tenha recebido licença dos sacerdotes para manifestar sua liberdade. O que ocorreu é que, não podendo conter a festa do bobo por meio de interditos, a Igreja, ainda que neoplatônica, acolheu a força híbrida do bobo a fim de debilitá-lo ao se fundir com a seriedade do sagrado.

\section{Palhaço}

Embora Heidegger e Koselleck tenham pensado a tradução como o vivido que se perde ou se desvia, outro caminho, no entanto, não há para pensar a palavra da cultura grega, senão traduzida para o latim e do latim, para o português. Assim, transliteraram os vocábulos gregos gelotopoiós por "bobo" e paliátsos por "palhaço", tendo pali o sentido de "outra vez, de novo" e atsos, de "desordenado, inconveniente". O movimento desordenado do palhaço, que não convém ao sério, ao pesado, se repete como inconveniência. Bobo e palhaço, portanto, confraternizam-se.

Em 1513, quando se registrou pela primeira vez a palavra pagliaccio no dicionário, seu significado era "vestido ou feito de palha"; porém, por pertencer à natureza da palavra a instabilidade, pagliaccio quer dizer também "palha triturada", em 1547; adquire a ideia de "bufão de circo", em 1741; e, em 1841, a história registra "pessoa pouco séria que se comporta de modo ridículo e com pouca dignidade".

Pagliaccio é palavra italiana derivada de paglia, que por sua vez origina-se do latim paleae, "palha", produto do mundo rural a serviço dos homens e dos animais. No estábulo, a palha, que mantém a temperatura dos 
animais à noite e alimenta-os no inverno, possui também função higiênica, porque os animais que dormem sobre a palha são mantidos afastados do lugar onde esses mesmos animais deixam fezes e urina. Já na casa do homem comum e no palácio do rei, a palha é útil para forrar colchões e travesseiros. Mais: cobrem-se casas rurais e estábulos com palhas. Bem mais, dê-mais: na primitiva roupa do palhaço, a palha enchia e afofava o tecido colorido e irregular com a finalidade de proteger a alegria do palhaço das quedas causadas por suas travessuras, por sua desordem. O palhaço é, pois, aquele que é vestido ou feito de palha, mas palha com o sentido do que foi escrito até aqui, ou seja, isto: dentro do estábulo, a palha aquece, alimenta e separa o sujo do limpo; como cobertura da casa e do estábulo, a palha protege; e, no quarto do palácio e do casebre, a palha proporciona repouso, descanso, sono.

Essa é a ordem natural do objeto palha na rotina do mundo rural; seu estado não natural, porém, só ocorre à medida que se instaura a desobediência da transfiguração: de palha (no estábulo), o palhaço exala o calor de cores e de formas, nutre os mortais de afetos felizes e, quando a palha separa o sujo do limpo, o palhaço separa dos homens as impurezas objetivas da realidade; de palha (no travesseiro do palácio ou do casebre), o palhaço, que proporciona sonhos, é fissura entre o invisível e o visível; de palha (sobre o estábulo ou sobre o casebre), o palhaço, homem de palha que nos cobre, protege a criança, assim como Guido, pai de Giosué, protege seu filho com metáforas no belíssimo filme A vida é bela (1997), de Roberto Benigni, elevando a alegria da criança acima da verdade de homens. Porque o amor de Guido brinca, ele oferta ao filho o sagrado ócio de rirem juntos da estável superfície aparente das coisas.

Objeto da ordem do campo, do ciclo da terra, a palha é útil; porém, quando o ser humano a colocou pela primeira vez sob a roupa colorida e irregular a fim de proteger a alegria das quedas causadas pelas travessuras, pelas brincadeiras, a palha perdeu sua função de ser útil, porque, quando se modelou ao corpo humano para proteger a alegria, ela aparenta ser o próprio corpo do homem. Não mais, portanto, objeto útil, mas objeto transfigurado enquanto homem de palha.

Tempos modernos (1936), de Charles Chaplin; e Doutores da alegria (2005), de Mara Mourão, são filmes em que o homem de palha movimentase contra o trabalho alienado da fábrica e contra a tristeza do sofrimento no leito hospitalar. Se em estado natural a palha cumpre sua função segundo a ordem externa, o homem de palha é aquele que reage à ordem objetiva do mundo.

Ainda sim, palhaço, embora sendo, o que é? Como foi dito, o homem de palha nega a ordem natural dos objetos: "uma paisagem poderá ser bela, graciosa, sublime, insignificante ou feia, porém jamais risível" (BERGSON, 1978, p. 12). Com efeito, por causa da natureza da palha, não rimos dela, porém rimos quando uma forma foi dada à palha, molde da fan- 
tasia humana que ela assumiu, ou seja, finge-se homem de palha: palhaço. Porém, sob a roupa multicolorida e irregular, qual o sentido de o objeto palha fingir ser o corpo do homem? Distanciar-se de sua condição natural; afastar-se de sua servilidade fixa de ser palha, por isso o sentido de fingir-se, porque, ao se distanciar de sua condição natural, ao se afastar de sua sujeição - e, por fingir, distancia-se, afasta-se -, a palha desvia-se da determinação de significado único (monossêmico) a fim de, porque é dada a ela uma forma, habitar no reino alegre da polissemia, onde a palha se transfigura, e, transfigurada como homem de palha, o palhaço se opõe à ordem séria do mundo. Fingir é isto: ficção.

Qual a natureza desse fingěre? Das linguagens ficcionais, a menos direta, a mais polissêmica, a mais misteriosa delas expressa, por causa do significante excedente, a harmonia do jogo assimétrico e, por ser assimétrico, revela-se ocultando; linguagem cuja origem comungava com o sagrado das Musas, dos versículos bíblicos, isto é, separava-se do comum, do ordinário; linguagem que não poderia ser outra a não ser esta: classificada por Aristóteles de ciência, qual seja, ela: poíesis. Essa tem princípio nas ações do sujeito, mas tais ações são dirigidas a produzir algo fora do próprio sujeito, por exemplo, produções de arte. Conforme definição em $O$ Banquete, de Platão, os gregos entendiam por poíesis o que faz algo passar do não ser ao ser.

Esse, no entanto, não é o sentido do palhaço que circula no cotidiano comum da sociedade hodierna; não há memória autêntica na rotina mecânica das obrigações diárias para falar do que seja a originalidade do palhaço na polis, talvez porque a cidade tenha se transformado em objeto denso e opaco da seriedade, só ela tão útil. "O homem necessitado, carregado de preocupações, não tem senso para o mais belo espetáculo", escreveu Karl Heinrich Marx (1818-1883), aos 26 anos, em Manuscritos Econômico-Filosóficos, de 1844. Em outra obra, Teses contra Feuerbach, de 1845, Marx difunde a ideia de que "não cabe mais ao filósofo interpretar o mundo mas transformá-lo" (1985, p. 53) por meio da praxis - conceito em que o homem demonstra a verdade, verdade que o autor de $O$ Capital define como efetividade e poder. Assim, os termos correlacionam-se: transformação-praxis-verdade. Mas essa praxis cabe a Carlitos? A praxis do palhaço transforma a realidade e revela a verdade? As respostas ficariam incompletas se não houvesse antes outra pergunta: o que é praxis? Da origem, que é aristotélica, a Marx, a ideia central de praxis permanece como enraizamento na existência biológica, quer dizer, como vontade, como apetite, como impulso vital. O substantivo praxis, editado pelo tempo histórico, não se encontra hoje diferente ou contraditório do que era antes, porque, como foi escrito, o sentido de praxis permanece o mesmo de Aristóteles a Karl Marx, qual seja, enraizamento na existência biológica. O substantivo praxis não foi destruído pelo personagem Syme na $11^{\mathrm{a}}$ edição do dicionário. Na edição do tempo histórico, entretanto, o que ocorreu com 
a palavra praxis foi bem mais fino, primoroso, sutil, bem mais dissimulado.

Semelhante a um fagócito, o substantivo praxis envolveu, englobou e digeriu outro substantivo ao longo da história, promovendo um tipo de absorção cuja finalidade resultou no mais profundo esquecimento de poíesis, a palavra envolvida, englobada e digerida porque se integrou ao conjunto conceitual do fagócito praxis. Como consequência dessa fagocitose conceitual, a produção artística entra, também ela, na dimensão da praxis aristotélico-marxista. Assim, ao lermos Marx, lemos a digestão definitiva de praxis. Só anterior a esse arranjo, porém, vemos poíesis a fim de lê-la antes da formação do fagossomo, ou melhor, antes da formação "fagossemântica" - esse antes chama-se Aristóteles (384/383 a. C - 322 a. C).

Para o Estagirita, a palavra praxis não só se separa de poíesis como esta se encontra em um posto mais alto do que aquela. Encontra-se acima porque poíesis não é enraizamento na existência biológica, não é enraizamento na existência orgânica, instrumental, cíclica, fechada. Embora seja atividade produtiva, poíesis, ainda sim, não é atividade produtiva conforme a praxis, pois, partindo da etimologia, poíesis vem de poieîn (produzir), enquanto praxis vem de práttein (fazer), no sentido de agir. Como "produzir" não se compara ao "fazer", o que é então "pro-duzir"? Em sua origem, "pro" tem o sentido de "ir para adiante, avançar"; e "duzir", de origem duco, significa "levar, transportar". Quem vai para adiante é porque "saiu de, avançando em direção a", trans-portando-se de um lugar para outro. Inegável que "pro-dução" diz respeito a movimento, quer dizer, ao devir. "Pro-duzir", portanto, é movimentar-se do não ser ao ser, da ocultação à luz. Poíesis é isto: o que Martin Heidegger chama de "aberto", o que Maurice Blanchot chama de "fora", o que Gilles Deleuze chama de "dobra". Uma vez ao aberto, Carlitos, como todo palhaço, não explica a realidade; e sim possibilita, entre ele (homo ludens) e o operário (homo faber), expressar não outro mundo, mas o outro do mundo.

E a palavra praxis? Se ela é pro-dução, já sabemos que, antes da "fagossemântica", praxis não é a pro-dução de poíesis. Da origem práttein, prático significa "fazer" ou "agir fácil". Que praxis é ação, já sabíamos, mas por que "fácil"? Em sua etimologia, "fácil" tem a mesma origem de "face" (facěre), quer dizer, o que é feito fácil só é fácil porque se apresenta na "superfície da face", no ser da face, onde, por estar tudo à mostra, tudo se encontra à luz, logo, não existe nada ocultado, ou seja, como não existem dobras, tudo é simples. Por isso, a doxa ou o senso comum afirma que a verdade é o "fato", o que se vê às claras na superfície, na face da realidade. Ora, a praxis, diferente da poíesis, não é o aberto ou as dobras porque a praxis é superfície, aparência, doxa, senso comum, e só é isso porque a praxis é o agir fácil e, por ser visível à luz do dia, é linguagem reduzida, retraída, fechada em si mesma, não re-flexiva; fechada por ser ela, a praxis, objeto superficial. Portanto, longe de ser o des-velamento de poíesis, a praxis obstrui o acesso ao real negado por ser ela, a praxis, obtusa, vontade 
que se move e vai até o limite biológico de si mesma. Como consequência da praxis, só há o mesmo mundo, e não o outro do mundo, não havendo, pois, des-velamento porque existe tão somente a linguagem ordinária, instrumental, monossêmica, fácil, imediata, pre-visível da práxis, não se irrompendo, por causa disso, o interior oculto, ele: o verso. À medida que essa linguagem, a ob-jetiva, afirma o real não negado, a linguagem da poíesis, a sub-jetiva, é sempre a realização de algo irreal, do real negado. O real negado não é o que existe, porém o que, por existir fechado, permite a nós o acesso fácil, imediato, utilitário, dando a impressão de que nada nos falta; e o irreal, por sua vez, não é o que não existe, mas é o que, ocultado pela superfície à luz do dia, nos falta - não por outro motivo, bobos e palhaços são isto: estética da sobra.

\section{Dois filmes e uma só alegria Na fábrica}

Tempos Modernos é esse filme em que homens necessitados estranham o espetáculo da alegria. Podendo ser pensado por meio da palestra Lírica e Sociedade, do livro Notas de Literatura I, de Theodor W. Adorno (1903-1969), o palhaço Carlitos é guardião da linguagem infantopoética, que não expressa as impurezas da linguagem ordinária, e, por causa disso, o lírico se desfaz do peso da objetividade, permitindo expressar a imagem de uma "vida livre da coerção da prática dominante, da utilidade, da pressão da autoconservação obtusa" (1983, p. 195). Se o indivíduo experimenta a ordem social como hostil, alheia, opressiva, a linguagem lírica, com sua própria ordem, com sua própria lei, expressa a força do verso contra a prepotência da parte frontal das coisas, isto é, contra a superfície delas. Por isso, o outro lado, o lado oculto das coisas. Por isso, virar a página para ler o que é ocultado pelo anverso. Por isso, o verso. Contra a densidade da multidão, contra a opacidade do cotidiano, o lírico propaga seu canto subjetivo em uma sociedade onde a vida tornou-se alheia à pessoa humana. O mundo objetivo, o externo, a superfície, emudece a alma dos homens; a linguagem lírica, no entanto, não só fala o verso como, ao falá-lo, pro-voca o homem.

A lírica não é a voz ou o canto do poeta, ou de um indivíduo, ou de um sujeito histórico, mas a expressividade de um eu com a marca do Universal. Quando Adorno cita Hegel, ele afirma que o individual é mediado pelo Universal e vice-versa, ou seja, a linguagem lírica do palhaço contra a pressão social não é nada de individual, não é nada de sujeito histórico. O conteúdo lírico como conteúdo objetivo ocorre em virtude da subjetividade do lírico, que possui a natureza de se afastar da superfície social. É na linguagem estética do lírico que sub-jetividade vira objetividade, sem que as emoções sub-jetivas amadurecidas diluam-se a ponto de elas perderem a referência irrenunciável ao Universal (Espírito). Se 
resíduos de matéria não pesam mais na linguagem humana, é porque o lírico soa como força expressiva da vocalidade (ZUMTHOR, 1993, p. 150). Uma vez na linguagem lírica, que se afasta da superfície social, acontece o autoesquecimento do sujeito (histórico), que se põe ao dispor da linguagem como algo objetivo, assim como o que há de imediato e de involuntário em sua expressão. A linguagem lírica se mostra, portanto, garantida socialmente ali onde não fala na rotina, onde nada comunica na produção industrial.

\section{O palhaço na produção industrial}

Do diretor René Clair (1898-1981), A nós, a liberdade, de 1931, foi o filme que inspirou Charles Chaplin (1889-1977) para criar Tempos modernos, cuja primeira imagem é o grande relógio de fundo cinzento com seus números romanos metálicos marcando os segundos que restam para as 6 horas da manhã; na produção industrial, os ponteiros, uma vez vistos, imprimem o movimento das máquinas e regulam os corpos dos operários como se pertencesse à natureza humana a uniformidade dos cordeiros. Movimento do relógio. Movimento dos animais. Movimento dos trabalhadores. Movimento das máquinas.

Antes de o antioperário Carlitos surgir em cena, a linguagem a que assistimos pertence à ordem das coisas, linguagem em estado bruto porque se relaciona com a realidade das coisas enquanto coisas úteis, funcionais, usadas, calculadas, isto é, enquanto coisas instrumentalizadas. A linguagem da fábrica, portanto, coisifica. Nesse mundo, "não se consegue mais perceber nas palavras a violência que elas sofrem" (ADORNO; HORKHEIMER, 1985, p. 156). O palhaço percebe, ele retira das palavras a violência que as faz sofrer.

Surge Carlitos na condição primeira de operário. Submisso ao movimento da esteira, ele ajusta peças na linha de montagem, até que o movimento regular de seu corpo logo se altera quando sua mão coça rapidamente a axila. Inicia-se a sucessão gradual de desajustes. Submetido a trabalhar mais rápido porque o patrão gradativamente ordena aumentar a velocidade das máquinas, Carlitos, que não consegue acompanhar o movimento da produção por ter cometido o gesto irregular de se coçar, acaba sendo levado como peça pela esteira para dentro da engrenagem. Quando retorna ao ambiente de trabalho, Carlitos já retorna para brincar, para bailar, transformando suas duas ferramentas de trabalho em dois exagerados brincos, metáfora: sua linguagem agora já é poética, ele agora já é o antioperário, homo ludens. Se Carlitos é aquele que se afasta da superfície automatizada da fábrica, afasta-se porque ele encarna a expressão lírica - linguagem, segundo Adorno, não estranha ao sujeito. Uma vez linguagem lírica, o palhaço Carlitos instaura, entre máquinas e homens autômatos, a estranheza do improvável e do excesso, estranheza que nega o trabalho normal e objetivo por meio de uma 
aderência sub-jetiva. Mas entendamos que a subjetividade lírica, como pensa Adorno em sua palestra, capta o Universal no mergulho em si mesmo ou, ainda, desenvolve-se como sujeito autônomo, mestre da livre expressão de si mesmo. Nesse sentido, Carlitos é estética da alegria na forma de palhaço, imagem do antioperário. Em relação ao coletivo dócil, o palhaço é então diferença que não pode ser rebaixada à condição de objeto, à condição de praxis porque sua linguagem lírica representa a irrupção do que a superfície da produção industrial comprime do coletivo para baixo.

Mas como a produção industrial não pode parar, a estética da alegria, que é sobra, não pode ser sucessiva no tempo ou produzida em série na linha de montagem, por ser ela, a alegria do palhaço, desobediência momentânea que nos convida à reflexão sobre a vida, sobre o seu verso. Ora, como Carlitos desordenou a produção em série e como desestabilizou a seriedade da produção, o excesso e o improvável do palhaço necessitam ser curados a fim de que ele, uma vez normalizado, seja reconduzido à produção industrial. Colocada na ambulância, a subjetividade lírica do homem de palha precisa ser curada a fim de que Carlitos retorne ao mundo objetivo do trabalho. Caracteres do filme informam que Carlitos recuperouse da sua crise nervosa e, desempregado, deixa o hospital para começar uma vida nova; porém, antes de deixá-lo, o médico diz ao palhaço no corredor que ele tenha calma e não se excite. Embora Carlitos tenha recebido alta, a medicina não o curou porque, não estando na linha reta do patológico, o palhaço é linha ondulosa da alegria.

\section{No hospital}

Após 69 anos de Tempos Modernos, surge em 2005 o sensibilíssimo filme Doutores da Alegria, de Mara Mourão, onde palhaços não recebem alta dos médicos e muito menos são curados por eles; o ato de brincar agora cuida da natureza humana, fortalecendo o sistema imunológico "graça" à estética da alegria, que introduz na alma da criança não a "substância", mas "acidentes" que criam anticorpos. Se em 1936 o espaço sério da fábrica mecanizava a organização de corpos, o espaço também sério do hospital organiza o sofrimento. Tanto em um quanto em outro, na fábrica ou no hospital, manifesta-se o vazio de algo no que é humano; e o palhaço, sabedor disso, oferta seu corpo como excedente profuso de gestos leves, de fartas palavras felizes. O homem de palha se apresenta para expressar, mesmo em um hospital, que a vida ainda transborda em nós quando nela pulsam afetos felizes. "O contentamento nunca é excessivo" (SPINOZA, 2009, p. 184).

À medida que os créditos surgem, um mosaico de palhaços conduz nosso olhar a um bobo que nos convida para o espetáculo. Inicia-se o filme. No corredor do hospital, uma menina está sentada na cadeira. Depois que a câmera passa nosso olhar sobre o suporte de soro, o movimento da câmera 
permanece agora no traço de lápis preto sobre o olho esquerdo do palhaço, continuando o traço na trança de outra menina que reaparece andando em direção ao fundo do corredor hospitalar. Um monitor cardíaco, em primeiro plano, emite seu repetitivo som. Ao lado da máquina, uma criança em decúbito ventral, sozinha. Os objetos estão lá. Assim como eles, o som hospitalar também está como coisa. As crianças... estão só. Em outro espaço hospitalar, atores, ao som do violão, ao som da flauta, ao som do pandeiro, fan-tasiam-se. Uma vez palhaços, espalham-se: sempre em dois, a dupla caminha entre desenhos infantis pintados nas paredes do corredor; outros dois descem as escadas e, quando dobram à direita, a câmera lentamente detém nosso olhar a quatro telas que lembram van Gogh, enquanto em um dos quartos o "expressionismo" dos palhaços motiva o riso do menino Caio no "hospital bobo", onde um bom riso é método ótimo de relaxamento muscular. Isso ocorre porque os músculos não envolvidos pelo afeto do riso tendem a se soltar, eis a explicação para as pernas que ficam bambas, para a bexiga que se esvazia. Depois, quando a risada acaba, emerge a calmaria por causa da endorfina liberada pelos palhaços. Mais: melhora a circulação e a eficácia das defesas do organismo, aumentando a capacidade de resistir à dor. Para crianças como Caio, o ato expressivo do homem de palha diminui a medicação.

Extensão do conhecimento médico, o hospital, com suas linhas retas e com suas paredes monocromáticas, é o espaço da higiene que limpou a inutilidade do excesso. Mas o excesso do ato estético do palhaço é terapêutico. Em outros tempos, a desmedida dos loucos confinava-se em hospitais; porém, no filme Doutores da Alegria, o louco, já livre das linhas retas e das paredes com uma só cor, retornou ao hospital para cuidar, com doses não homeopáticas de alegria, doentes e não doentes. Quando dizemos cuidar, restrinjamo-nos a um dos conceitos da estética, qual seja, o significante.

Nas cenas iniciais, os atores, aos poucos, vestem-se de palhaço não porque colocam blusa, saia, calça - o que seria comum, óbvio -, mas porque seus corpos cobrem-se de cores, de linhas tortas, de traços incertos; cobremse do desequilíbrio entre significante e significado, permitindo a presença do significante excedente. O palhaço é o guardião desse desajuste, dessa assimetria. O palhaço é erro. Por causa dessa inconformidade, dessa estranheza entre significantes e significados, os signos linguísticos do hospital, até então estáveis, retraídos, ajustados, bem comportados, veem seus significados migrarem de significantes para outros significantes, por isso a criança ri em seu leito quando a seringa não é seringa mas flauta. Amálgama entre significante (forma) e significado (conteúdo), o ato estético do palhaço desmancha o objeto, retirando da seringa sua função fixa para transformá-la em sentido estranho ou incomum a ela mesma: metáfora. Dessa maneira, crianças são afetadas pelas paixões alegres por causa da 
natureza do palhaço, que é retirar dos signos do hospital a condição de objetos estáveis, tristes - espaço retraído pela dor e pelo saber científico.

\title{
Nem Aristóteles. Nem Descartes
}

Por não ser prisioneira da lógica aristotélica e nem da cartesiana, a criança enferma deleita-se diante dos palhaços, porque são eles os únicos no hospital que encarnam paradoxos que alegram inocentes almas com a não identidade: A não é igual a A. Ri-se da lógica clássica.

Mestra em psicologia e coordenadora do Centro de Estudo dos Doutores da Alegria, Morgana Masetti afirma no filme que "a realidade do hospital é transformada pelo olhar do palhaço porque não é cartesiano, onde as coisas estão mais divididas". O professor-doutor Yassuhiko Okay, vicepresidente da Faculdade de Medicina da Universidade de São Paulo, diz no final do filme:

\begin{abstract}
A medicina enxerga por fora e os doutores da alegria enxergam por dentro, por isso a medicina nunca será completa se não juntar o lado de fora com o lado de dentro e, portanto, ter uma visão integral do ser humano. A experiência com os doutores da alegria me mostrou o seguinte: que eles lidam exatamente com o lado invisível da realidade.
\end{abstract}

Por causa da geometria rígida do espaço-tempo hospitalar e por ser esse espaço-tempo sofrimento, o invisível de que fala o professor-doutor Yassuhiko encontra-se mais ainda retraído quando o médico anuncia a dor e, com ela, o vazio. O palhaço também anuncia no filme o triste; porém, diferente da seriedade médica, ele não traz o vazio; por causa do significante excedente, o homem de palha traz vida.

Embora sejam formados conforme os preceitos da ciência, psicóloga e médico concebem outra relação humana no hospital por causa da sabedoria do palhaço. A filosofia, como sabemos, importa-se com a pergunta, não com a resposta; a filosofia do palhaço, entretanto, diferente da filosofia séria, não se importa com a pergunta, porque, como observa a atriz Beatriz Sayad ou a doutora da alegria Valentina, o palhaço "se contenta em brincar com as perguntas".

\section{O dia em que Sócrates brincou}

Se a filosofia séria de Platão (427 a.C - 347 a.C) militarizou poíesis em A República (398a-b) e a de Aristóteles submeteu a comédia à última posição - depois da epopeia e da tragédia -, o saber da arte teatral de Aristófanes (447 a.C - 385 a.C) já tinha brincado com Sócrates (469 a.C 399 a.C) há um tempo em As Nuvens. Como sabemos, a comédia surgiu no final do século VI; e a Poética, de Aristóteles, no século IV, quer dizer, 
antes de o Filósofo classificá-la e antes de Platão condenar a desmedida poética, Sócrates brincara no palco de Dioniso. Terá ficado algum ressentimento nas filosofias platônica e aristotélica?

Comparada à narrativa epopeica e ao diálogo trágico, a comédia, perante filósofos que pensam a Ideia e a substância, é a única que se organiza intensamente por meio dos acidentes, sendo, pois, a mais híbrida delas. Porque o seu saber representa a ação contingente da vida, só restou à comédia, contrária à verdade pura, rir de Sócrates. A filosofia séria pergunta o que é o ser da coisa, o que é o ser em si, o puro, porém o saber de As Nuvens, que é mimético, retira Sócrates entre os homens a fim de representá-lo entre personagens, ou melhor, entre máscaras - palavra que no itálico significa demônio, ao passo que o latino larvo (máscara) designava no início um "espírito informal". Entre máscaras, o personagem Sócrates ludosofa.

Em estado natural, a face não motiva a alegria do riso; todavia, caso as linhas retas do rosto se contorçam, emergindo na superfície da pele trejeitos ou momices, a alegria de quem nos olha manifesta-se. Em outras palavras, entre o estado natural e o instável, entre ocultar o comum e revelar o estranho, entre anoitecer o regular e aclarar o assimétrico, no preciso momento desse encontro entre opostos na face, a alegria do bom encontro transforma-se em som expansivo do riso. No encontro transitório entre adversos que se atravessam, a alegria se solta como expressão desalinhada que nos afeta. Quando a face retornar ao seu repouso, ao permanecer estável, ao se conservar contida nela mesma, ela, jamais risível, não se alegra por causa do outro. Porém, quando o movimento interior do espírito (do ar, do sopro), em direção à superfície da pele, encontra-se com o repouso exterior do rosto, surge, na passagem entre o espírito e a pele, o excesso; eleva-se, na mediação entre o infinito e o finito, a sobra. Agora, sombreado por completo o estado natural das feições, iluminam-se os traços desmedidos e irregulares da aparência; tamanho deslimite, contudo, não tem, sabemos, função utilitária no mundo objetivo e sério do dia, pois, sem ter a função de praxis, a face do bobo e do palhaço é desnecessária por ultrapassar e assim por des-cobrir a natureza do que é. Mais: por ser desnecessária, é erro, e só é erro porque o erro do bobo e do palhaço se movimenta como extensão da sobra ou como o que não é ajustado às medidas do que é natural. Essa extensão da sobra, tão desnecessária por ser significante excedente, é o que é desinteressado ou ainda isto: ilusório. A ilusão encarnada nas faces do bobo e do palhaço só irrompe após a face natural e habitual da identidade ter sido sombreada. A ilusão é, portanto, isto: extensão, sobra.

Pelo que se escreveu nos últimos parágrafos, pergunta-se: podemos pensar que o riso é consequência do que foi desorganizado? Não rimos quando partes isoladas e fixas em si mesmas sustentam-se na ordem firme. Escrevemos no início deste artigo que o riso de Deus, o Único, gerou sete 
deuses por ter anulado a separação entre Afrodite (o Amor) e Ares (a Discórdia), neutralizando, por conseguinte, conflitos, combates, lutas. Porque uniu os contrários - ou desorganizou partes encerradas nelas mesmas -, Deus se alegrou; mas, pelo que foi pensado no parágrafo anterior, alegrou-se quando espírito e matéria se atravessaram na precisa passagem, na instante mediação em que germina a sobra, a fartura, ou seja, o inexato: ilusão - ou ainda isto: o falso, ou ainda ele: o irreal. Desorganizar a estabilidade é amalgamar os contrários, sendo que, desse desequilíbrio harmonioso, desse desajuste equilibrado, saltam-se espaços que fluem completos de excesso; arremessam-se extensões abstratas preenchidas de sobra.

Então, manifestar o espírito informal (ou a máscara) do bobo e do palhaço representa, ao mesmo tempo, cobrir o dia (face natural da identidade) e descobrir a noite (expressão estranha da contradição), imprimindo assim, nesse jogo de presença-ausência, outro movimento do real, a saber: a alegria, esse desajuste da sobra, da fartura, do inexato, da ilusão, do falso, do irreal. Eis, portanto, para ser alegre, ele: o ato desnecessário, sem função, por isso desinteressado, opondo-se, pois, ao latim pŏsĭtūră (ocupar posição, matar de cansaço); e mata-se de cansaço porque, conforme o significado segundo, existe o "trabalho de assentar". Em outras palavras, retomemos. A alegria do palhaço ou do bobo, que tanto ri da pǒsitūră (trabalho de assentar), é desinteressada por saber que, além de pǒsittüră ser "trabalho", "trabalho" origina-se do latim trĭpāl ̌̌s, termo a significar "instrumento de tortura, de torção". Por isso, para ser alegre, ela: palavra que, expressada pelo bobo e pelo palhaço, é a desinteressada ilusão, qual seja: im-postura. Por não desejar pôr, o bobo é im-postor; por não desejar (se) ajustar, o palhaço é inútil. Ambos, guardiões do ócio. Eles, que não se matam de cansaço para ocupar posição porque não trabalham para ajustar e muito menos para se ajustarem, não usam o instrumento que torce para ocupar o espaço. Para ser alegrar - esse afeto que nos expande, sentimento que nos alarga por ser encontro -, é preciso estar des-ocupado. "Bobo e palhaço são dois desocupados", é o que dizem. Nesse sentido, como não ocupa nenhuma posição na sociedade, a fan-tasia, que é livre, oferta-nos a nobre ilusão de nos sentirmos também desocupados. Fingir é fugir da ocupação. Ora, porque a produção ou a poíesis de ser bobo e de ser palhaço não pertence à praxis do fazer - a mesma de pǒsitūră -, a alegria não quer, não pode e nem deve se ajustar ao instrumento de torcer para assentar, para ajustar, para acomodar, para fixar - por isso bobo e palhaço são impostores e, para tanto haver a impostura, brincam.

Por que não se ajustar? Em Tempos Modernos, visualiza-se a resposta quando operários, adequados ao movimento-tempo da esteira industrial, ajustam parafusos em linha e, entre um torque e outro, a fabricação rotiniza sequências de rápidos intervalos, átimos de sucessivos vãos, tempo em que a matéria se ausenta. Nesses entreatos, como nada se 
excede, o contorno dos objetos permanece, porque esse vazio, também ajustado ao movimento-tempo da esteira industrial, é o limite oco da própria esteira industrial. Aqui, entre máquinas e autômatos, o vazio é útil, e é útil porque está ajustado, e está ajustado porque é instrumentalizado, e está instrumentalizado porque é funcional. Entre um torque e outro, a lacuna, duração de vácuo que, embora seja falta, é, ainda sim, matéria, mas matéria imperceptível de um oco que é coisa, de um vago que é objeto reificado, ou seja, ao não esvaziar essa realidade concreta, o autômato operário não a transforma em meio imaterial, diáfano, espaço capaz de acolher combinações que ele mesmo poderia inventar, afastando o espírito da praxis ou do fazer biológico superficial. Entre a luz diária da fábrica e o sono noturno da casa, agrimensa-se a produção expressiva de Carlitos. De repente, se coça, produzindo um movimento e um tempo a mais, excedente que se desprende do vazio e do contorno dos objetos para criar o espaço e, nele, o deslimite, desajuste que motiva em nós a alegria do riso. Carlitos, agora, antioperário, palhaço, desmancha ou desalinha os contornos do objeto por causa de sua impostura inicial de se coçar, criando e ampliando gradualmente, por causa do significante excedente, o espaço da alegria. Em posições de trabalho, os operários se mantêm ajustados à linha de montagem; eles conservavam a postura, menos Carlitos, esse im-postor que ilude, que joga, que brinca. Então, respondamos: por que não se ajustar? $\mathrm{Na}$ cadeira, uma peça desajustada a deixa mole, flexível; porém, caso seja ajustada, a cadeira cumpre sua reta e segura função, que é nos servir de assento. Não só: ao ser ajustada, a justa peça neutraliza a folga, a desocupação ou o espaço desinteressado; anula a força do que é falho, errante, largo; enfim: anula a força do que é falso, plástico: a sobra.

\section{0 capitalismo também brinca}

Nesses tempos tão sérios e pilhados de coisas úteis, escrever sobre o bobo e sobre o palhaço é escrever sobre cadáveres, inutilidades sepultadas na cova rasa da indigência. $O$ mundo infantil nem reconhece mais seus defuntos no Instituto Médico Legal. Crianças há muito são acolhidas pela estética agradável do shopping, onde o consumo as alegra neste templo mítico das marcas. Alegria, entretenimento utilitário. Criança, pequeno proprietário. Ela não assiste mais à invenção do mundo e muito menos o inventa, utiliza-o; pois, sem saber o que é o palhaço e muito menos o que ele conta, o adulto presenteia a inocência com gestos sem encontros, sem o imprevisível, sem a aventura. Gestos sem a fan-tasia. Para o bebê que chora por não querer comer, a mãe ameaça chamar o palhaço, por isso, quem sabe, a pequena Larissa de Macedo Machado tenha confessado que, quando criança, sentia muito medo de palhaço, até hoje Anitta se assusta com suas cores, com suas formas, com seu riso, com suas brincadeiras. Crianças se alegram ao som do funk de MC Vilãozin, de 6 anos, e de MC Melody, de 8 
anos. A infância não se identifica mais com a inocência do homem de palha.

Palavra consumida pela linguagem ordinária da doxa, palhaço não passa de instrumento sonoro de que o falante faz uso com toda a verdade sua (de senso comum) para emitir o que não sabe sobre o sentido mais original da palavra palhaço. Assim, à criança que chora para não comer, a mãe fala o incompreensível, porque, do palhaço (ou do bobo), resta tão somente uma carcaça de fonemas, cadáver chamado significante. Sem mais significar o que é, palhaço é palavra sem memória que apenas designa o que não é. Como foi escrito em um parágrafo anterior, não se consegue mais perceber nas palavras a violência que elas sofrem.

A linguagem infantil, aos poucos, cedeu sua inútil e desnecessária polissemia - ou impossibilidade da linguagem alcançar a coisa - ao vazio da útil palavra-cópia da realidade. Evidencia-se na cultura de massa o seguinte: o infantil perdeu sua força estética ${ }^{3}$. Embora o bobo e o palhaço brinquem em torno do mesmo centro polissêmico da criança, esse centro separou-se dele mesmo, tornando-se comportamento apartado de sua finalidade. O brincar, em nossa sociedade, é ocasional, tal qual a presença do santo no cotidiano, impedindo aos homens o livre acesso ao brincar original. Nesse sentido, o sagrado separa e subtrai a fim de inutilizar, a fim de indispor. Bobo e palhaço sacralizaram-se porquanto, uma vez separados de suas finalidades, perderam força estético-poética. Então, como trazer ao livre uso dos homens e das crianças o bobo e o palhaço? Como, ao livre uso dos homens e das crianças, unir a estética da alegria à sua finalidade? "É preciso haver o jogo como órgão profano, porém o jogo como órgão da profanação está em decadência em todo lugar" (AGAMBEN, 2007, p. 67), compreendendo o profano como o que é devolvido ao uso e à propriedade dos homens. Por todo canto, porém, o capital faz as contas e, cada vez mais e mais, multiplica novos e velhos jogos. A nova liturgia, os jogos televisivos de massa. "O que não pode ser usado acaba, como tal, entregue ao consumo ou à exibição espetacular" (Ibid, 2007, p. 71). O capitalismo retirou da palavra brinquedo, portanto, sua originalidade. Detalhemos. Se o brincar autêntico cessa-se na cultura capitalista, a boneca da menina se reduz a objeto frio. Então, em um segundo momento, o capitalismo a captura a fim de batizá-la Barbie nas águas sagradas do mercado infantil. Será que, por não ser consumo e nem espetáculo, o palhaço ainda pode se unir à sua finalidade? Mas, para unir, é preciso brincar, profanar. E nós sabemos o que é ainda brincar?

A fim de concluir, descortinamos um labirinto conceitual inerente à insolência alegre e criadora do bobo e do palhaço, infanto-poéticos

\footnotetext{
${ }^{3}$ De 1977 a 1986, o lúdico não erótico recebeu audiência de uma geração de crianças por meio das imagens do Sítio do Pica-Pau Amarelo, quando, em 30 de junho de 1986, o teleMonteiro Lobato saiu de cena para ir ao ar o lúdico erótico de o Xou da Xиха. Doze anos após a rainha dos baixinhos disseminar a beleza de suas curvas, Gilberto Felisberto Vasconcellos publicaria pela editora Espaço e Tempo o livro O Cabaré da Xuxa.
} 
desfigurados pela incompreensão do senso comum. Nestas páginas, porém, eles se apresentaram como força do espírito não determinada pela história, sabemos: bobos e palhaços nem pertencem à história. No filme Hotxuá, a transfiguração nos remete a origens de "cultos secretos" (mystérion), pertencendo, pois, à natureza do êxtase místico. Filetes de água dessa fonte a-histórica, bobo e palhaço pertencem à natureza do espírito: movimento para fora, do não ser ao ser. Eles, que surgem do oculto, filhos da noite, são fan-tasmas (fan-tasias) que expressam o que a luz do dia oculta ou emudece. Porque visitou a alegria que pulsa antes das filosofias sérias de Platão e de Aristóteles, Nietzsche pôde escrever em Assim falou Zaratustra (p. 35) que "a criança é a inocência, e o esquecimento, um novo começar, um brinquedo, uma roda que gira sobre si, um movimento, uma santa afirmação". Se brincar é sempre movimento extensivo, brincar é sobra e, por ser sobra, nos alegra - a criança é essa sobra assim como sobra também são os bobos e os homens de palha.

\section{Referências bibliográficas}

ADORNO, T. W. Lírica e sociedade. Coleção Os pensadores. $2^{\mathrm{a}}$ edição. São Paulo: Abril Cultural, 1983.

ADORNO, T. W; HORKHEIMER, M. Dialética do esclarecimento. In: A indústria cultural: o esclarecimento como mistificação das massas. Rio de Janeiro: Jorge Zahar, 1985. p. 113-156.

AGAMBEN, G. Profanações. São Paulo: Boitempo, 2007.

ARISTÓFANES. As nuvens. Coleção Os pensadores. São Paulo: Abril Cultural, 1972.

ARISTÓTELES. Arte poética. Rio de Janeiro: Ediouro, [198-].

BARTHES, R. Elementos de semiologia. 19a edição. São Paulo: Cultrix, 2012.

BENJAMIN, W. Reflexões: a criança, o brinquedo, a educação. São Paulo: Summus, 1984.

BERGSON, H. O riso. $2^{\circ}$ edição. Rio de Janeiro: Guanabara, 1987.

BRANDÃO, J. de S. Mitologia grega. Petrópolis, Rio de Janeiro: Vozes, 1991. v.2.

DICIONÁRIO Grego-Português e Português-Grego. Portugal: Porto, 1997.

HOUAISS, A. Dicionário da língua portuguesa. Rio de Janeiro: Objetiva, 2001.

HUIZINGA, J. Homo ludens. 5a edição. São Paulo: Perspectiva, 2008.

LAVELLE, L. Ciência estética, metafísica, crônicas filosóficas. São Paulo: Realizações, 2012.

LEVY, T. S. A experiência do fora: Blanchot, Foucault e Deleuze. Rio de Janeiro: Civilização Brasileira, 2011.

MARX, K. Manuscritos econômico-filosóficos. Coleção Os pensadores. $3^{\text {a }}$ edição. São Paulo: Abril Cultural, 1985. 
MINOIS, G. História do riso e do escárnio. São Paulo: Unesp, 2003.

NIETZSCHE, F. Assim falava Zaratustra. $12^{\mathrm{a}}$ edição. Rio de Janeiro: Ediouro, [entre 1986 e 1990]

PLATÃO. A República. $6^{\mathrm{a}}$ edição. Lisboa: Fundação Calouste Gulbenkian, 1990.

Íon. Belo Horizonte: Autêntica, 2011.

SARAIVA, F. R. dos S. Novíssimo dicionário latino-português. Rio de Janeiro: Garnier, 2000.

SPINOZA, B. de. Ética. In: Quarta parte: a servidão humana ou a força dos afetos. Belo Horizonte: Autêntica, 2013.

VALÉRY, P. Eupalinos ou o arquiteto. Rio de Janeiro: Editora 34, 1996.

VASCONCELLOS, G. F. O cabaré das crianças. Rio de Janeiro: Espaço e Tempo, 1998.

VIARO, M. E. Por trás das palavras: manual de etimologia do português. São Paulo: Globo, 2004.

ZUMTHOR, P. A letra e a voz. São Paulo: Companhia das Letras, 1993.

\section{FILMES}

A NÓS, a liberdade. Direção: René Clair. Produção: René Clair. Roteiro: René Clair. Gênero: drama cômico. Elenco Principal: Alberto Broquin; André Michaud; Germaine Aussey; Henri Marchand; Jacques Shelly; Léon Courtois; Léon Lorin; Marguerite De Morlaye e outros. França: Films Sonores Tobis, 1931, 1 DVD (1h 44min)

A VIDA é bela. Direção: Roberto Benigni. Produção: Gianluigi Braschi e Elda Ferri. Coprodução: Mario Cotone, Agnès Mentre e John Rogers. Roteiro: Roberto Benigni e Vincenzo Cerami. Fotografia: Tonino Delli Colli. Figurino: Danilo Donati. Música: Nicola Piovani. Direção de Arte: Danilo Donati. Edição: Simona Paggi. Elenco Principal: Roberto Benigni; Nicoletta Braschi; Giorgio Cantarini; Giustino Durano; Sergio Bini Bustric; Marisa Paredes. Gênero: drama cômico. Itália: Melampo Cinematografica,1997, 1 DVD (1h 57min).

DOUTORES da alegria. Direção: Mara Mourão. Produção Executiva: Fernando Dias. Direção de Produção: Maurício Dias. Coordenação de Produção: Tatiana Battaglia. Fotografia: Hélcio Alemão Nagamine. Montagem: Rodrigo Menecucci. Música Original: Arrigo Barnabé. Edição de Som: Miriam Biderman. Som Direto: Paulo Ricardo Nunes. Direção de Arte: Marcelo Righini com Wellington Nogueira. Elenco: Wellington Nogueira; Angelo Brandini; César Gouvêa; Beatriz Sayad; Cláudia Zuccherato. Gênero: documentário. Brasil: Europa Filme, 2006, 1 DVD (1h 37min).

TEMPOS modernos. Direção: Charlie Chaplin. Produção: Patriciu Santans. Roteiro: Charles Chaplin. Fotografia: Ira H. Morgan e Roland Totheroh. Música: Charlie Chaplin. Elenco Principal: Charlie Chaplin; Paulette 
Goddard; Henry Bergman; Stanley Sandford; Chester Conklin. Gênero: drama cômico. Estados Unidos: United Artists, 1936, 1 DVD (1h 27min). HOTXUÁ. Direção: Gringo Tardia e Letícia Sabatella. Produção: José Gonzaga Araújo. Roteiro: Letícia Sabatella, Gringo Cárdia, Alessio Slossel e povo krahô. Editor: Quito Ribeiro. Fotografia: Sylvestre Campe. Som Direto: Heron Alencar, Bruno Espírito Santo e Denilson Campos. Trilha Sonora Original: Paulo Santos. Indigenista: Fernando Schiavini. Elenco: nativos da aldeia Krahô. Gênero: documentário. Brasil: Caliban Produções Cinematográficas, 2009, 1 DVD (1h 10min). 